Gi rask respons på artikler gjennom artikkelens kommentarfelt på tidsskriftet.no. Respons som er postet innen én måned etter at artikkelen er publisert, vurderes for publisering som Brev til redaktøren i papirutgaven.

Redaksjonen forbeholder seg retten til å foreta redaksjonelle endringer.

Forfattere av vitenskapelige artikler har tilsvarsrett, jf. Vancouver-gruppens regler.

\section{Det menneskelige}

Merete Telstø skiller i Tidsskriftet nr. 14/2012, slik jeg forstår henne, mellom grupper basert på personers grad av identifikasjon med bestemte identiteter (1). Medisinsk hørselsstatus er i denne forbindelse ikke relevant. Jeg personlig kjenner til mennesker som medisinsk sett ville blitt definert som lett tunghørte, men som kaller seg selv for døve. Dette fordi de definerer seg selv som døve identitetsmessig. Døv identitet handler om språk (tegnspråk) og kultur, ikke medisinsk hørselsstatus. Det handler heller ikke om å ha en funksjonshemning, men at man føler tilhørighet til en kulturell og språklig minoritetsgruppe.

Når hun refererer til forskning som konkluderer med at «døve i større grad enn tunghørte aksepterer sin funksjonshemning» (1), tror jeg altså det handler om identitet og tilhørighet kontra medisinsk hørselsstatus og funksjonshemning. Tegnspråkmiljøet (eller døv identitet) byr på en mulig sosial tilhørighet uavhengig av hørselsstatus. De personer, enten de er døve eller tunghørte medisinsk sett, eller hørende for den saks skyld, som ikke føler tilhørighet til en del av samfunnet, vil naturligvis falle ut på en eller annen måte. Sånn sett er det problematisk å snakke om psykososiale fenomener med utgangspunkt i medisinske kategorier, hørselshemmet, tunghørt, døv, hørende. Det handler om det menneskelige, om det å være et menneske.

\section{Hilde Gjermundrød}

hilde.gjermundrod@gmail.com

Hilde Gjermundrød (f. 1986) er psykolog ved Nasjonalt senter for hørsel og psykisk helse, Oslo universitetssykehus.

Oppgitte interessekonflikter: Ingen

\author{
Litteratur
1. Telstø M. Hørselshemmet blant hørende. Tidsskr Nor Legeforen 2012; 132: \\ 1592.
}

Publisert som rask respons i nettutgaven 11.7.. 2012.

\section{Telstø svarer:}

Sikring av funksjonshemmedes helse og deres mulighet til å leve et mest mulig normalt liv står sentralt i FNs konvensjon om økonomiske, sosiale og kulturelle rettigheter (ØKS) (1). Staten skal altså sikre retten til helsetilbud på et ikke-diskriminerende grunnlag, særlig at disse også sikres for sårbare og marginaliserte grupper. Retten gjelder altså den høyest oppnåelige helse, jf. konvensjonens artikkel 12. Oppnåelsen av dette avhenger dels av forholdene i samfunnet som helhet, sosialt og miljømessig, forholdene i den gruppen eller det miljøet, enten det er tegnspråkmiljø eller normaltfungerende miljø, der personen har sitt liv, og situasjonen for den enkelte selv (2). I FNs konvensjon for personer med nedsatt funksjonsevne av 13. desember 2006 (3), artikkel 3 om generelle prinsipper pkt. h finner vi i utgangspunktet retten til identitet for funksjonshemmede - den lyder som følger: «Respekt for de utviklingsmuligheter som barn med funksjonshemming har, samt respekt for deres rett til å bevare deres identitet».

Bevaring av identitet er også nedfelt i FNs konvensjon om barnets rettigheter av 20.november 1989 (4), artikkel 8 som lyder: «1. Partene forplikter seg til å respektere barnets rett til å bevare sin identitet, herunder statsborgerskap, navn og familieforhold som anerkjent av loven, uten ulovlig innblanding. 2. Dersom et barn ulovlig blir fratatt sin identitet helt eller delvis, skal partene yte egnet bistand og beskyttelse med henblikk på hurtig gjenoppretting av hans eller hennes identitet.» Plikten til å legge forholdene til rette for samtaler om egen hørsel, gjelder i utgangspunktet for alle voksne og barn. Dette innebærer at norsk helsetjeneste skal kunne legge forholdene til rette, slik hørende og hørselshemmede på menneskerettslig grunnlag får si sin mening om eget valg av språk, kommunikasjon, identitet og hørsel.

\section{Merete Telstø}

miamte@online.no

Merete Telstø (f. 1963) har jobbet med kulturformidling for hørselshemmede i regi av Kulturdepartementet.

Ingen oppgitte interessekonflikter.

\section{Litteratur}

1. Konvensjon om økonomiske, sosiale og kulturelle rettigheter. www.globalis.no/ Avtaler/Konvensjon-om-oekonomiske-sosiale-og-kulturelle-rettigheter (10.9.2012).

2. Eide A. Retten til helse som menneskerettighet. Nordisk Tidskrift for menneskerettigheter 2006; 24: 274-290

3. FN-konvensjon om rettighetene til mennesker med nedsatt funksjonsevne. www.regjeringen.no/nb/dep/bld/tema/likestilling-og-diskriminering/ funksjonsnedsettelser/fn-konvensjon-om-rettighetene-til-mennes.html?id= 511768 (10.9.2012).

4. FNs barnekonvensjon. www.regjeringen.no/upload/kilde/bfd/red/2000/0047/ ddd/pdfv/178931-fns_barnekonvensjon.pdf (10.9.2012).

\section{Mer enn molekyler}

I Tidsskriftet nr. 14/2012 belyses avhengighetsfaren ved kvetiapin (1). Det er bra at potensialet for misbruk av antidepressiver blir kartlagt og tatt på alvor. Samtidig er det overraskende at en artikkel som omtaler avhengighet ikke nevner de psykologiske faktorene som spiller inn. Avhengighet av medisiner som bedøver og demper angst er en ekstern og midlertidig løsning på et internt problem. Så lenge det ikke blir tatt tak i årsaken til problemet, vil avhengighet bli en logisk konsekvens (2).

\section{Ruben Solvang}

post@rubensolvang.com

Ruben Solvang (f. 1985) er teknisk rådgiver / web-utvikler.

Oppgitte interessekonflikter: Ingen

\section{Litteratur}

1. Aa E, Helland A, Spigset O. Kvetiapin kan ha misbrukspotensial. Tidsskr Nor Legeforen 2012; 132: 1619-20.

2. Maté $G$. In the realm of hungry ghosts: close encounters with addiction. Berkeley: North Atlantic Books, 2010

Publisert som rask respons i nettutgaven 20.8. 2012 